\title{
Morphology and Genetic Diversity of Mud Crabs (Portunidae: Scylla) from Teluk Sulaman, Sabah, Malaysian Borneo
}

\author{
Ruhana Hassan ${ }^{1,2^{*}}$ and Durrah Syazwani Mustapah ${ }^{1}$ \\ ${ }^{I}$ Faculty of Resource Science and Technology, Universiti Malaysia Sarawak, \\ 94300 Kota Samarahan, Sarawak \\ ${ }^{2}$ Centre for Pre-University Studies, Universiti Malaysia Sarawak, \\ 94300 Kota Samarahan, Sarawak
}

\begin{abstract}
Teluk Sulaman, Sabah, is a secluded area that is rich in biological resources but with minimal biodiversity information. Small scale mud crab fisheries exist in Teluk Sulaman to support local livelihood, but there is a tendency of overfishing due to the increasing demand of this resource. The diversity of mud crab in Teluk Sulaman is still unknown. Information on the diversity of mud crab is vital, not only for conservation purpose but also to support the utilisation of this valuable resource sustainably. Therefore, this study aimed to identify the species of mud crabs in Teluk Sulaman, using morphological and molecular approaches. Based on morphological data, Teluk Sulaman only supports one species of mud crab, namely Scylla tranquebarica. The $460 \mathrm{bp} 16 \mathrm{~S}$ rRNA gene obtained in this study matched $S$. tranquebarica (GenBank Accession No.: KM258653.1), thus supported the conventional method of species identification. The phylogenetic trees agreed that $S$. tranquebarica is monophyletic. However, the relationship between $S$. serrata and $S$. olivacea remains unresolved. Future studies should explore spatial and temporal sampling besides using other genetic markers to further understand mud crab population in Teluk Sulaman further.
\end{abstract}

Keywords: mud crab Scylla; diversity; 16S rRNA gene; Teluk Sulaman

\section{INTRODUCTION}

Mud crab or mangrove crab, genus Scylla, could be found in the estuaries and mangroves of Africa, Australia and Asia (Keenan et al., 1998). Mud crabs live inside burrows in the mud of estuaries and mangrove areas, where the waters are sheltered from currents and wave actions (Le Vay, 2001). The shell colour varies; from a deep, mottled green to very dark brown. World Register of Marine Species 2018 (WoRMS, 2018) and Keenan et al. (1998) recognised four mud crab species, namely Scylla serrata (Forskal, 1775), S. olivacea (Herbst, 1796), $S$. tranquebarica (Fabricius, 1798), and S. paramamosain (Estampador, 1949). Local Malaysian refers to mud crab as 'ketam nipah', 'ketam bakau' (Rosli et al., 2017;
Ikhwanuddin et al., 2011) or 'kepiting bakau'. In the mangroves, adult mud crabs are important in assisting decomposition of organic matters such as detritus from dead plant and animals as they scavenge for almost anything. This will further speed up the nutrient recycling process and energy flow in the mangroves. Earlier descriptions of mud crabs life history stated that their diets are made up of algae, decaying woods and bamboo sticks (plant-based materials), but mud crabs are best described as omnivores (Shelley and Lovatelli, 2011).

Mud crabs are in demand as a quality food due to their size, meat content and delicate taste (Azra and Ikhwanuddin, 2016; Kwong, 2012). Increasing human population and market demand had elevated the pressure on the supply of mud crabs wild populations and possibly 
also triggered by over-exploitation (Ikhwanuddin et al. 2015). Mud crab aquaculture in Malaysia is relatively new (Kwong, 2012; Gong et al., 2015; Fatihah et al., 2017) and still depends on supplies of juveniles stocks from the wild, hence studies to improve the mud crab aquaculture industry is still on-going (Gong et al., 2015; Fatihah et al., 2017).

Sabah, situated in the North Borneo, is one of the mega biodiversity hot spots in the world (de Bruyn et al., 2014). Teluk Sulaman, Sabah is an area with a good potential of fisheries, but only limited attention is paid into it, due to competition with many other notable areas with economic importance in the state. Teluk Sulaman is rich in biological resources and supports various ecosystems due to its location at the river mouth that connecting the bay with the South China Sea. This place is located at the east coast of Sabah; has brackish water and mangrove forests in the surroundings and adjacent to a forest reserve, Hutan Simpan Bukit Lema'as. The human population of Teluk Sulaman is made up of Bajau Sama ethnicity, and they called mud crab 'gawa' or 'surih'. There are small scale mud crab fisheries in Teluk Sulaman, involving local fishermen, who used custom-made trap baited with chicken meat or trash fish. Mud crabs caught are either for domestic consumption or sold in the small stalls in the village to generate a small sum of household income.

Mud crabs in the genus Scylla have high morphological characters plasticity. Therefore, the taxonomic confusion occurs (Fushimi and Watanabe, 1999; Sorower et al. 2017). In addition, Ikhwanuddin et al. (2011) claimed that any documentation on species level for mud crab produced before 1998 are less reliable in comparison to recent studies. As technology advanced, DNA information, in particular, the DNA sequencing data, could aid in species identification with the advantage of its ability to identify cryptic and polymorphic species as well as could provide insights into the complicated history of unknown organisms (Schander and Willasen, 2005). Sorower et al. (2017) reported that the first internal transcribed spacer (ITS-1) marker and phylogenetic trees constructed based on 16S rRNA sequences had resolved the taxonomic problem of commonly found mud crab in Bangladesh, clarifying those previously identified as $S$. serrata should be $S$. olivacea. There are several studies which focused on the genetics of mud crabs in Malaysia, for example, Rosly et al. (2017), Naim et al. (2012) and Sharif et al. (2016). However, none of those studies had used samples from
Teluk Sulaman. Hence the diversity of mud crabs exist in Teluk Sulaman is still not documented. Therefore, the objective of this study was to determine the diversity of mud crabs from Teluk Sulaman, using a combination of morphological assessment and 16S rRNA gene analysis.

\section{MATERIALS AND METHODS}

Collection of 30 samples of mud crabs was done in Teluk Sulaman, Sabah (Figure 1) in September 2017 with the help of local fishermen. Each specimen was given a Voucher number, TSo1-TS30, followed by morphological assessment and pictures of the specimens were taken as records. Fresh tissue of approximately $2 \mathrm{~cm} \times 2 \mathrm{~cm}$ was collected from the right cheliped of each sample after the completion of morphological assessments. Tissues for DNA work were kept in cold condition of approximately $4^{\circ} \mathrm{C}$ during transportation to the Aquatic Molecular Laboratory, Universiti Malaysia Sarawak. Upon reaching the laboratory, all samples were kept in $-20^{\circ} \mathrm{C}$ freezer until further DNA analysis. Species identification followed Keenan et al. (1998), Shelley and Lovatelli (2011), Ikhwanuddin et al. (2011) and Trivedi and Vachhrajani (2013). The distinctive morphological features used in the identification of the species are: (i) the shape and appearance of the frontal lobe spines, (ii) the appearance of spines in propodus and carpus, and (iii) the presence of polygonal patterns and colour on the cheliped, legs and abdomen. Morphometric data collected were measurements of carapace width (CW) and carapace length (CL) (Din et al., 2017). The measurements were taken using an electronic digital calliper (Precision), up to $0.01 \mathrm{~cm}$. Morphometric data was analysed using descriptive statistics, namely mean of CW and CL, with standard deviation as well as the maximum and minimum values of the measurements. Student T-test had been carried out to determine if there is any significant difference between measurements of male and female mud crabs.

Total genomic DNA extraction from mud crab tissue samples were carried out using modified CTAB protocol (Doyle and Doyle, 1987) with the addition of Proteinase K; followed by $1 \%$ Agarose Gel Electrophoresis (AGE) with $1 \mathrm{~Kb}$ DNA ladder as the ruler. DNA extraction product later became DNA template in Polymerase Chain Reaction (PCR) to amplify the $16 \mathrm{~S}$ rRNA gene following modified protocols 
by Palumbi (1991) and Imai et al. (2004), with forward primer 16SAR-L (5'-CGC CTG TTT ATC AAA AAC AT-3'), reverse primer 16SBR-H (5'-GGT TTG AAC TCA GAT CAT GT-3'). Standard PCR cocktail of the total volume of $25 \mu \mathrm{l}$ was prepared with one negative control for each batch. PCR was run in thermocycler (Biometra TAdvanced) according to the following thermal profile: one cycle of predenaturation at $92^{\circ} \mathrm{C}$ for 5 minutes, 30 cycles of denaturation, annealing and extension at $92^{\circ} \mathrm{C}, 45^{\circ} \mathrm{C}$ and $72^{\circ} \mathrm{C}$, respectively for 30 seconds on each step ,and 1 cycle of final extension at $72^{\circ} \mathrm{C}$ for 5 minutes. All PCR products were then subjected to $1 \%$ AGE with 100 bp DNA ladder as the ruler.

CHROMAS PRO program was used to observe the quality of the chromatogram, and the text sequence obtained, followed by BLAST to confirm the species. Then, CLUSTAL $\mathrm{X}$ was used to carry out multiple alignments of the DNA sequences while MEGA 7.0 (Kumar et al., 2016) was used to calculate genetic distance using Kimura 2-parameter model and to construct a phylogenetic tree. DNA sequences of other mud crabs were also taken from the GenBank to be included in the analysis, with blue swimming crab as the outgroup. Two phylogenetic trees were constructed following Nei and Kumar (2001), namely: (i) NeighborJoining (NJ) tree using Bootstrap Method (Felsenstein, 1985) with p-distance model and (ii) Maximum Likelihood (MP) tree using Bootstrap Method (Felsenstein, 1985) with Tamura-Nei model.

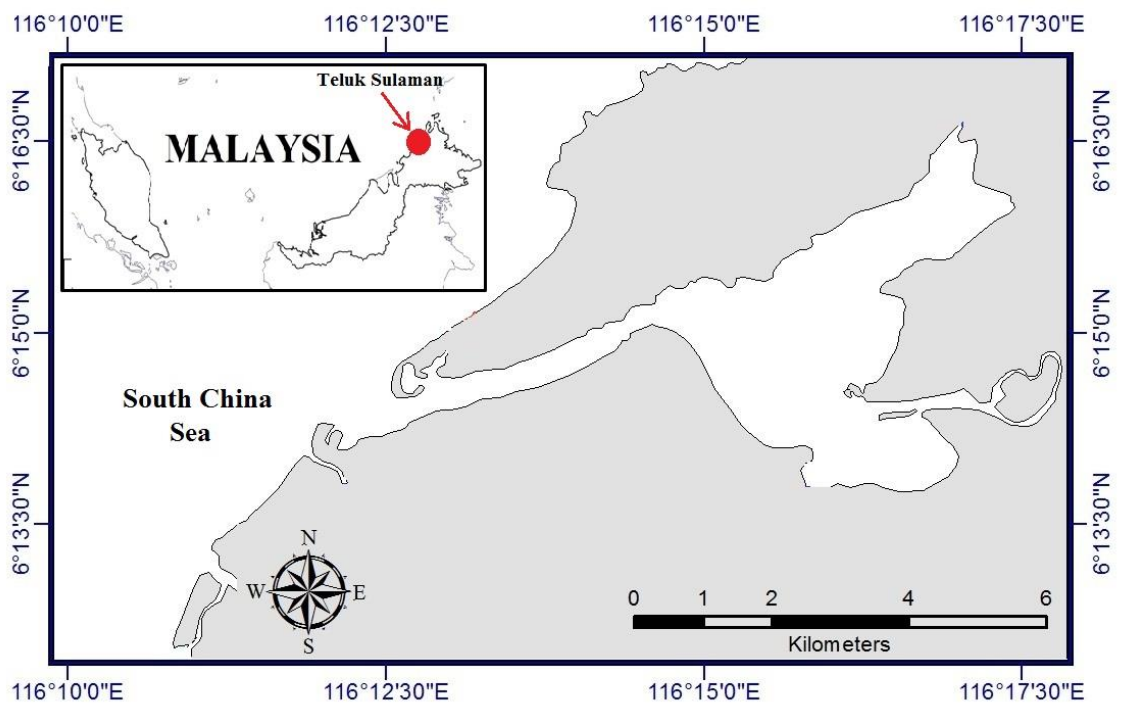

Figure 1. Mud crab sampling site - Teluk Sulaman, Sabah, Malaysian Borneo

\section{RESULTS}

\section{A. Morphological Assessment}

All 30 samples obtained in this study were identified as Scylla tranquebarica based on morphological data. Frontal lobe spines of $S$. tranquebarica were blunted and moderate in height. In the cheliped, both of the carpus spines, as well as the propodus spines, were easy to observe. Fresh samples had purple colouration on the lower part of the body, especially around the abdomen and on the cheliped. For male specimens, no colour patterns had been observed.
Male and female of $S$. tranquebarica sample could be differentiated based on the shape of the abdomen; male mud crabs have narrow, triangular shape while female mud crab has broader and globular abdomen.

Table 1 summarises morphometric data of $S$. tranquebarica obtained in this study. Male had CL of $9.9 \pm$ $1.3 \mathrm{~cm}$ and $\mathrm{CW}$ of $6.9 \pm 1.0 \mathrm{~cm}$ while female recorded CL of $10.5 \pm 1.1 \mathrm{~cm}$ and $\mathrm{CW}$ of $7.4 \pm 0.9 \mathrm{~cm}$. A $t$-test revealed that there is no significant difference between male and female of $S$. tranquebarica in terms of carapace measurement $(\alpha=$ 0.05). 
Table 1. Descriptive analysis of the measurements on carapace of mud crabs. $\mathrm{n}=30$. Min: minimum, Max: maximum, $\mathrm{N}$ : number of samples, SD: standard deviation, CL: carapace length, CW: carapace width

\begin{tabular}{|l|c|c|c|c|c|c|c|c|}
\hline & \multicolumn{4}{|c|}{ Male } & \multicolumn{4}{c|}{ Female } \\
\cline { 2 - 9 } & $\begin{array}{l}\text { Min } \\
(\mathrm{cm})\end{array}$ & $\begin{array}{c}\text { Max } \\
(\mathrm{cm})\end{array}$ & $\mathrm{N}$ & $\begin{array}{c}\text { Mean with SD } \\
(\mathrm{cm})\end{array}$ & $\begin{array}{c}\text { Min } \\
(\mathrm{cm})\end{array}$ & $\begin{array}{c}\text { Max } \\
(\mathrm{cm})\end{array}$ & $\mathrm{N}$ & $\begin{array}{c}\text { Mean with SD } \\
(\mathrm{cm})\end{array}$ \\
\hline CL & 8.0 & 11.8 & 17 & $9.9 \pm 1.3$ & 8.7 & 12.7 & 13 & $10.5 \pm 1.1$ \\
\hline CW & 5.4 & 8.3 & 17 & $6.9 \pm 1.0$ & 6.2 & 9.7 & 13 & $7.4 \pm 0.9$ \\
\hline
\end{tabular}

\section{B. The $16 S$ rRNA Gene Sequence Analysis}

In this study, all DNA sequences obtained matched the $16 \mathrm{~S}$ rRNA gene sequence of Scylla tranquebarica (Accession No.: KM258653.1) originated from the Philippines, with 99\% similarity. From a total of 460 aligned bases, 379 sites (82.4\%) were conserved while 81 sites (17.6\%) were variable.

The mean total nucleotide composition was 36.5\% A, 34.8\%

$\mathrm{T}, 18.0 \% \mathrm{C}$ and $10.7 \% \mathrm{G}$. The intraspecific genetic distance for Scylla species were in the range of value between o $0.2 \%$, including the values of genetic distance for $S$. tranquebarica samples from this study with $S$. tranquebarica from other countries (Table 2). $S$. tranquebarica obtained more than $2 \%$ genetic distance with all other species; values of 3.6-4.0\% with $S$. paramamosain; 5.4-5.7\% with $S$. serrata; 5.4-5.9\% with S.olivacea and 15.1$15.4 \%$ with $P$. pelagicus.

Table 2. Pairwise distance analysis (in percentage) using Kimura 2-parameter model

\begin{tabular}{|l|c|c|c|c|}
\hline & S.tranquebarica & S. paramamosain & S. serrata & S. olivacea \\
\hline S. tranquebarica & $0-0.2$ & & & \\
\hline S. paramamosain & $3.6-4.0$ & $0-0.2$ & & \\
\hline S. serrata & $5.4-5.7$ & $7.4-7.9$ & $0-0.2$ & $0-0.2$ \\
\hline S. olivacea & $5.4-5.9$ & $7.4-7.9$ & $0-0.4$ & $16.5-16.7$ \\
\hline P. pelagicus & $15.1-15.4$ & $15.7-15.9$ & $16.5-16.8$ & \\
\hline
\end{tabular}

Figure 2 and 3 describe the phylogenetic relationship among Scylla spp. S. tranquebarica had grouped into the same clade with other $S$. tranquebarica with high bootstrap value (100\% for NJ tree and $99 \%$ for ML tree in Clade A). Therefore, $S$. tranquebarica is monophyletic. Other than that, $S$. paramamosain had also formed its clade, namely
Clade B, with strong bootstrap values, $100 \%$ in both NJ and ML trees. Hence, $S$. paramamosain is also monophyletic. In contrast, $S$. serrata and $S$. olivacea had been grouped into the same clade (Clade C), with high bootstrap values of $100 \%$ in NJ and ML trees, suggesting that $S$. serrata and $S$. olivacea are not monophyletic. 


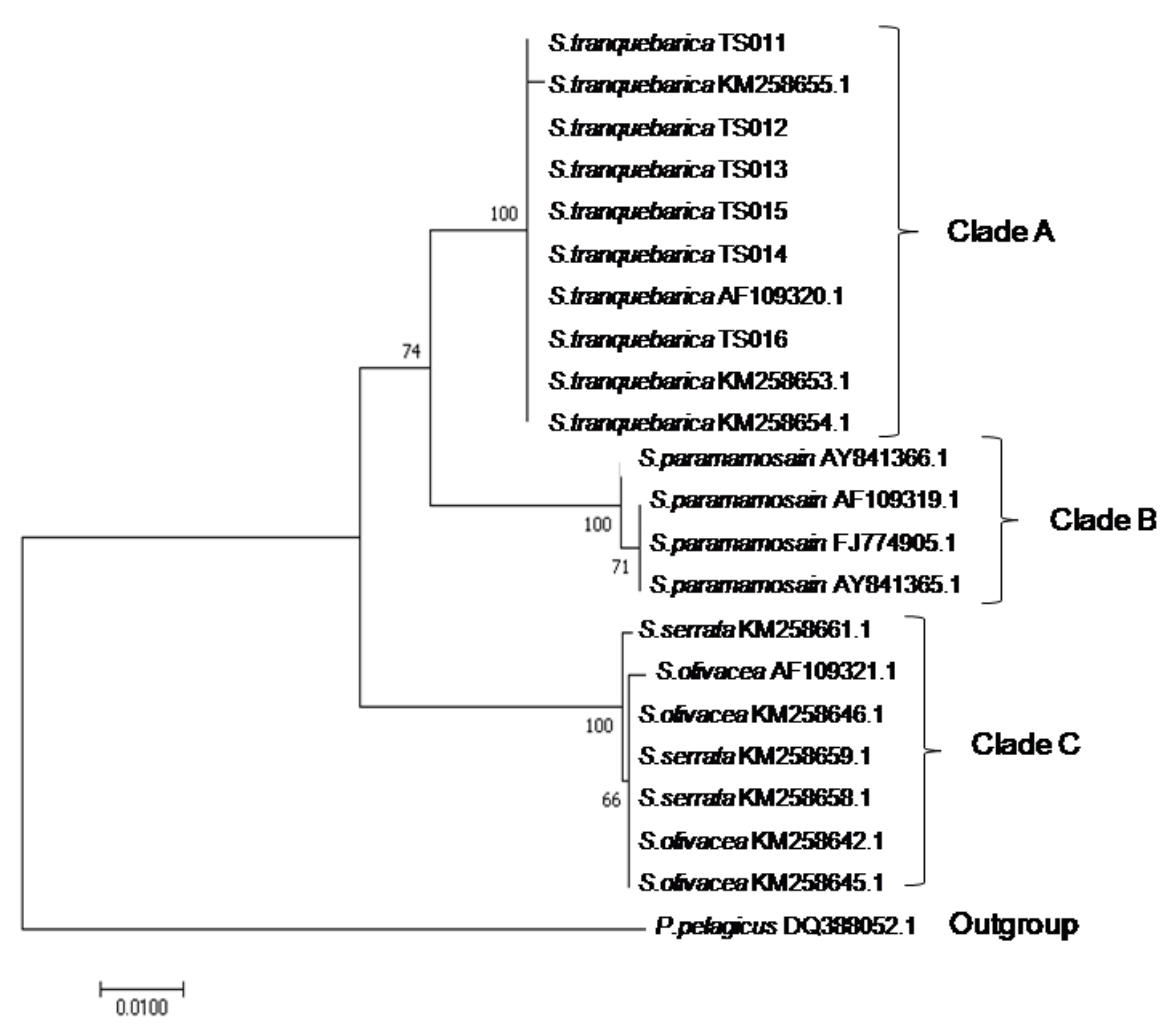

Figure 2. Neighbour-Joining phylogenetic tree constructed using 16S rRNA gene sequences showing the relationship among Scylla spp. with $P$. pelagicus as outgroup

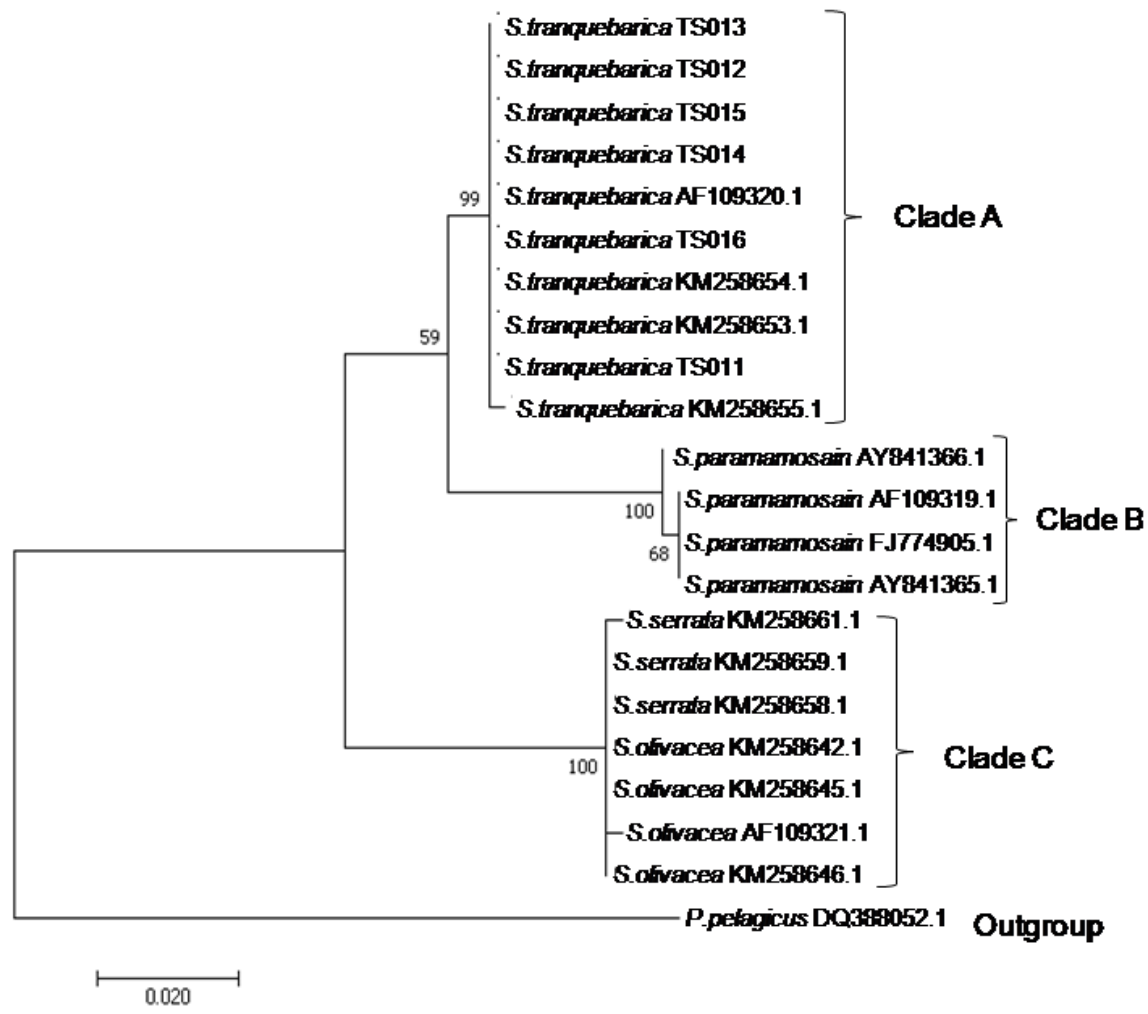

Figure 3. Maximum Likelihood phylogenetic tree constructed using 16S rRNA gene sequences showing the relationship among Scylla spp. with $P$. pelagicus as outgroup 


\section{DISCUSSION}

\section{A. Morphological Assessment}

All 30 mud crab samples obtained from Teluk Sulaman were identified as Scylla tranquebarica (Fabricius, 1798) as the morphological characteristics matched description by Keenan et al. (1998), Din et al. (2017), Trivedi and Vachhrajani (2013), Shelley and Lovatelli (2011), and Ikhwanuddin et al. (2011). S. tranquebarica is acknowledged as purple mud crab due to its purplish shell colouration. In this study, the fresh mud crab samples were purplish on the abdomen and the last two pairs of the legs. However, this characteristic (purple colour) is also shared with fellow Scylla member, S. serrata. In addition, Keenan et al. (1998) stated that the presence of polygonal patterns on the cheliped, legs and abdomen could also be used as a character to aid species identification. However, in this study, the polygonal patterns were either weakly present or could not be observed at all. For male specimens, no such pattern could be seen. For the females, weak polygonal patterns were seen on the cheliped and the first pair of the leg, whereas stronger polygonal pattern can be observed on the last two pairs of the legs.

For CL, Trivedi and Vacchrajani (2013) obtained a mean of $43.89 \pm 13.14 \mathrm{~cm}$ for mud crabs in Gujarat India while Keenan et al. (1998) did not include the value of CL in their report, although the ratio of CL to internal CW was provided. In this study, the mean for CL is smaller than the mean mentioned above, both for male and female specimens. For CW, Keenan et al. (1998) obtained a mean of $12.08 \pm 1.23 \mathrm{~cm}$ within the measurement range of $10.25-14.38 \mathrm{~cm}$ from 24 individual of $S$. tranquebarica samples, while Trivedi and Vacchrajani (2013) obtained a mean of $67.62 \pm 17.31 \mathrm{~cm}$. Both of the studies had recorded a larger mean of CL in comparison to this study.

Larger size mud crabs had been reported by Trivedi and Vachhrajani (2013) in Gujarat, India, compared to the mud crabs in Teluk Sulaman. The mangrove area in Gujarat is the second largest in India, with total cover area of $1103 \mathrm{~km}^{2}$. Conservation and development of this area are of high importance, resulting in an increase in the mangrove cover of approximately $45 \mathrm{~km}^{2}$. The conservation and preservation of the mangrove in Gujarat has resulted in a healthy ecosystem which had probably allowed the wildlife to grow to more than its typical size. In contrast, Teluk Sulaman is not a forest reserve and people harvest mud crabs regularly for local consumption. It is also possible that the size of mud crab varies among localities as habitat quality, water quality parameters, genetics and other biotic factors are said to influence the growth of marine organisms.

There is no significant difference in the mean CL and CW between male and female specimens in this study. In contrast, a study conducted on blue swimming crab, Portunus pelagicus (Decapoda, Brachyura, Portunidae) had suggested that there is a sexual dimorphism (Sanchez et al., 2013). This contrasting result might be due to larger sample size examined by Sanchez et al. (2013) as well as the usage of multiple landmarks (measurements) across the whole carapace of the crab, compared to only two measurements used in this study. This discrepancy may also due to different taxa, although mud crab and blue swimming crab are belonging to the same Family Portunidae.

Male mud crabs have narrow, triangular shape abdomen while the female has wider and globular abdomen. Sexual dimorphism shown in crabs is likely due to the reproductive role played by the females (Rufino et al., 2004 and Sanchez et al., 2013).

\section{B. Molecular Analysis}

Total genomic DNA extraction had been successful using a modified CTAB protocol (Doyle and Doyle, 1987). In other molecular studies of mud crabs, methods of DNA extraction includes DTAB-CTAB method (Sharif et al., 2016), AquaGenomic Solution Kit (Naim et al., 2012), Get pure DNA kit-Tissue (DOJINDO Molecular Technologies) (Imai et al., 2004) and traditional Proteinase $\mathrm{K}$ and phenolchloroform extraction protocol (Ma et al., 2012; 2016a). Other notable methods that had been successful in extracting DNA from Portunidae are phenol-chloroformisoamyl alcohol with volume ratio 25: 24:1 by Ma et al. (2016b). In the study of porcelain crabs, QIAGEN DNeasy Blood and Tissue Kit had been successful in isolating the DNA (Baeza, 2016).

After series of systematic PCR optimisation, the amplification of $16 \mathrm{~S}$ rRNA gene of approximately between 
$400 \mathrm{bp}$ to $500 \mathrm{bp}$ had been successful for mud crabs in this study, similar to Imai et al. (2004). The $16 \mathrm{~S}$ rRNA gene sequences obtained during this study matched to of $S$. tranquebarica (Accession No.: KM258653.1, sample from the Philippines) with $99 \%$ similarity. Therefore $16 \mathrm{~S}$ rRNA gene information supported the morphological assessment data, where all samples were confirmed as a single species, namely $S$. tranquebarica.

The genotype and haplotype of $S$. serrata, S. olivacea and S. paramamosain had been successfully distinguished by Imai et al. (2004). Their findings had opened the doors for other studies, including the distribution range of mud crab larvae, environmental factors that may affect the growth and survival of the juveniles as well as for breeding purposes. Keenan et al. (1998) had also been successful in amplification of the 16S rRNA gene from mud crabs, which later subjected to Unweighted Pair-Group Method using Arithmetic Averages (UPGMA) clustering. Results from Keenan et al. (1998) suggested that there are at least four different mud crabs species, thus using that knowledge, the morphological data of the mud crabs had been critically examined.

Bradley and Baker (2001) had introduced the Genetic Species Concept, with the following guidelines: (i) genetic divergence value of more than $11 \%$ indicates species recognition, (ii) values of $2-11 \%$ indicates high possibility of non-specific population, and (iii) value lesser than $2 \%$ is categorized as intraspecific variation. The genetic divergence values among $S$. tranquebarica sequences in this study and those obtained from GenBank showed less than $0.2 \%$, coherent with the Genetic Species Concept (Bradley and Baker, 2001). S. tranquebarica sequences show about 3.6 4.0\% genetic distance with $S$. paramamosain and $5.4-5.9 \%$ genetic distance with both $S$. serrata and $S$. olivacea, which indicated that the individuals came from different species. It is noted that $S$. serrata and $S$. olivacea are closer to each other, with genetic divergence value of only $0-0.4 \%$. This may be due to high similarity in the genetic entity for the 16S rRNA gene for both species.

In this study, both phylogenetic trees show similar topology. $S$. tranquebarica is monophyletic, similar to the report by Keenan et al. (1998). Using COI gene analysis, Ma et al. (2012) and Rosly et al. (2017) had also reported that $S$. tranquebarica is monophyletic. Phylogenetic trees in this study show $S$. olivacea and $S$. serrata are grouped into one clade, supported by strong bootstrap value, which is $100 \%$ for both NJ and ML trees. Thus they are not monophyletic. The presence of both species in one clade can also be explained by the low genetic divergence among them (Table 2). In contrast, studies by Keenan et al. (1998) had indicated that $S$. serrata and $S$. olivacea were reciprocally monophyletic. Using other genes (COI gene) information, Ma et al. (2012) and Rosly et al. (2017) also supported Keenan et al. (1998) in terms of both species status as monophyletic.

\section{CONCLUSION AND RECOMMENDATION}

Findings of this study highlight the presence of $S$. tranquebarica in Teluk Sulaman, a mud crab species endemic to the mangroves of the South China Sea. Both morphological data and 16SrRNA gene analysis are congruent in the species identification of the mud crab. There is no sexual dimorphism can be seen in $S$. tranquebarica, except male and female can be differentiated by the shape of the abdomen. Phylogenetic analysis reveals that $S$. tranquebarica is monophyletic. Future studies should examine more samples and involve many other measurements (abdominal width and length, length of merus, length of the carpus, length of palm and length of dactylus), and explore other gene markers for example COI gene, ITS-1 region and DNA microsatellite to further understand the mud crab population in Teluk Sulaman.

\section{ACKNOWLEDGEMENTS}

Authors would like to thank local people of Teluk Sulaman, Sabah for their help during field sampling. Thank you to Dr Wan Zabidii Wan Morni for his help in preparing the map (Figure 1). Nevertheless, thank you to UNIMAS for chemicals, consumables and equipment used in this study. There are no potential conflicts of interest between the parties involved in this study. 


\section{REFERENCES}

[1] Azra, MN \& Ikhwanuddin, M 2016, 'A review of maturation diets for mud crab genus Scylla broodstock: present research, problems and future perspective', Saudi Journal of Biological Sciences, vol. 23, pp. 257-267.

[2] Baeza, JA 2016, 'Molecular phylogeny of porcelain crabs (Porcellanidae: Petrolisthes and allies) from the southeastern Pacific: the genera Allopetrolisthes and Liopetrolisthes are not natural entities', PeerJ-Aquatic Biology Section.

DOI: $10.7717 /$ peerj.1805.

[3] Bradley, RD \& Baker, RJ 2001, 'A test of the genetic species concept: cytochrome-b sequences and mammals', Journal of Mammalogy, vol. 82, no. 4, pp. 960-973.

[4] Din, NMB, Das, SK, \& Bakar, Y 2017, 'Carapace width-weight relationship of the mud crab (Scylla tranquebarica Fabricius, 1798) from the waters of Peninsular Malaysia', Indian Journal of Geomarine Sciences, vol. 46, no. 8, pp. 1667-1672.

[5] De Bruyn, M, Stelbrink, B, Morley, RJ, Hall, R, Carvalho, GR, Cannon, $\mathrm{CH}$, van den Bergh, G, Meijaard, B, Metcalfe, I, \& Boitani, L 2014, 'Borneo and Indo-China are major evolutionary hotpots for Southeast Asian biodiversity', Systematic Biology, vol. 63, no. 6, pp. 879-901.

[6] Doyle, JJ \& JL, Doyle 1987, 'A rapid DNA isolation procedure for small quantities of fresh leaf tissue', Phytochemical Bulletin, vol. 19, pp. 1115 .

[7] Fatihah, SN, Julin, HT \& Cheng, CA 2017, 'Survival, growth, and moulting frequency of mud crab Scylla tranquebarica juveniles at different shelter conditions', AACL Bioflux, vol. 10, no. 6, pp.1581-1589.

[8] Felsenstein J 1985, 'Confidence limits on phylogenies: An approach using the bootstrap', Evolution, vol. 39, pp. 783-791.

[9] Fushimi, H \& Watanabe, S 1999, Problems in species identification of the mud crab genus Scylla
(Brachyura: Portunidae), UJNR Technical Report (28), pp. $9-13$.

[10] Gong, J, Yu, K, Shu, L, Ye, H, Li, S, \& Zeng, C 2015, 'Evaluating the effects of temperature, salinity, starvation and autonomy on moulting success, moulting interval and expression of ecdysone receptor in early juvenile mud crabs, Scylla paramamosain', Journal of Experimental Marine Biology and Ecology, vol. 464, pp.11 - 17.

[11] Ikhwanuddin M, Azmie G, Juariah HM, Zakaria MZ, \& Ambak MA 2011, 'Biological information and population features of mud crab, genus Scylla from mangrove areas of Sarawak, Malaysia', Fisheries Research, vol. 108, pp.299-306.

[12] Ikhwanuddin M, Lan SS, Abdul Hamid N, Fatihah SN, Azra MN, Siti Aisah A \& Abol-Munafi AB 2015, 'The embryonic development of orange mud crab, Scylla olivacea (Herbst, 1796) held in captivity', Iranian Journal of Fisheries Sciences, vol. 14, no. 4, pp.885-895

[13] Imai, H, Cheng, JH, Hamasaki, K \& Numachi, KI 2004, 'Identification of four mud crab species (genus Scylla) using ITS-1 and 16S rDNA markers', Aquatic Living Resources, vol. 17, pp. 31-34.

[14] Kumar, S, Stecher, G, \& Tamura, K 2016, 'MEGA 7.0: Molecular Evolutionary Genetics Analysis version 7.0 for bigger datasets', Molecular Biology and Evolution, vol. 33, pp. 1870-1874.

[15] Kwong, KO 2012, 'Mangrove crab aquaculture in Malaysia', Graduate Infolink, vol. 3, pp 7.

[16] Keenan, CP, Davie, PJF, \& Mann, DL 1998, 'A revision of the genus Scylla de Haan, 1833 (Crustacea: Decapoda: Brachyura: Portunidae)', Raffles Bulletin Zoology, vol. 46, pp. 217-245.

[17] Le Vay, L 2001, 'Ecology and management of mud crab Scylla spp.', Asian Fisheries Science, vol. 14, pp. $101-111$.

[18] Ma, HY, Ma, CY, \& Ma, LB 2012, 'Molecular identification of genus Scylla (Decapoda: Portunidae) based on DNA barcoding and 
polymerase chain reaction', Biosystematics and Ecology, vol. 41, pp. 41-47.

[19] Ma, HY, Ma, CY, Zhu, JJ, Ren, GJ, Wang, W, Chen, W, Lu, JX, \& Ma, LB 2016a, 'Characterization of the complete mitochondrial genome and phylogenetic relationships of the three-spot swimming crab (Portunus sanguinolentus)', Genetics and Molecular Research, vol. 15, no. 3. DOI: $10.4238 /$ gmr.15038580.

[20] Ma, CY, Ma, HY, Ren, GJ, Wang, W, Chen, W, Lu, JX, Zou, X, \& Ma, LB 2016b, 'Characterization of the complete mitochondrial genome of Portunus pelagicus with implications for phylogenomics', Genetics and Molecular Research, vol. 15, no. 3.

DOI: $10.4238 /$ gmr.15038719.

[21] Naim, DM, Rosly, HAM, \& Nor, SAM 2012, 'Assessment of phylogenetic inter-relationship in mud crab genus Scylla (Portunidae) based on mitochondrial DNA sequence', in International Conference on Applied Life Sciences (ICALS2012), Turkey, September 10-12, 2012, Turkey: IntechOpen. pp. 269-275

[22] Nei, M \& Kumar, S 2000, Molecular Evolution and Phylogenetics, UK: Oxford University Press.

[23] Palumbi, SR 1996, 'Nucleic Acids II: the polymerase chain reaction', eds Hillis DM, Moritz, C, \& Mable BK, in Molecular Systematics, Sunderland, Mass.: Sinauer, pp. 205-247.

[24] Rosly, HA, Mohd Nor, SA, \& Md Naim, D 2017, 'Phylogenetic relationships within the Scylla (Portunidae) assessed by the mitochondrial DNA sequence', Biodiversitas, vol. 18, no. 4, pp. 16961704.

[25] Rufino, M, Abelló, P, \& Yule AB 2004, 'Male and female carapace shape differences in Liocarcinus depurator (Decapoda, Brachyura): An application of geometric morphometric analysis to crustaceans', Italian Journal of Zoology, vol. 71, no. 1 , pp. $79-83$.

DOI: $10.1080 / 11250000409356554$.

[26] Sanchez, MLS, Gorospe, JG, Gorospe, JN, Torres, MAJ, \& Demayo, CG 2013, 'Describing geographic differences in carapace shape in the blue swimming crab Portunus pelagicus from

Mindanao Bays, Philippines', International Journal of Bioflux Society, vol. 6, no. 6, pp. 622634.

[27] Schander, C \& Willasen, E 2005, 'What can biological barcoding do for marine biology?', Marine Biology Research, vol. 1, no. 1, pp. 79-83.

[28] Sharif, NAM, Kahar, NAS, Rodrigues, K, Ransangan, J, \& Yong, ASK 2016, 'Genetic diversity of mud crabs, Scylla tranquebarica in Sabah, Malaysia based on Cytochrome C Oxidase (COI) gene sequence', Songklanakarin Journal of Science and Technology, vol. 38, no. 4, pp. $365-$ 372.

[29] Shelley, C \& Lovatelli, A 2011, Mud crab aquaculture: A practical manual, FAO Fisheries and Aquaculture Technical Paper, no. 567, Rome, Italy.

DOI:http://www.fao.org/docrep/o15/bao110e/bao 110e.pdf.

[30] Sarower, MG, Md Shahriar, SI, Nakamura, H, Abdur Rouf, M \& Okada, S 2017, 'Taxonomic confirmation of mud crab species (genus Scylla) in Bangladesh by nuclear and mitochondrial DNA markers', Mitochondrial DNA Part A, DNA Mapping, Sequencing and Analysis, vol. 28, no. 6, pp. 935-940.

DOI: $10.1080 / 24701394.2016 .1214726$.

[31] Trivedi, JN \& Vachhrajani, KD 2013, 'Taxonomic account of genus Scylla (de Haan, 1833) from Gujarat State, India with two new records of species', Arthropods, vol. 2, no. 4, pp. 159 - 171.

[32] WoRMS Editorial Board 2018, World Register of Marine Species, viewed 21 August 2018, $<$ http://www.marinespecies.org > DOI:10.14284/170. 